Acta Theriologica 39 (3): 295-305, 1994.

PL ISSN 0001-7051

\title{
Seasonal variation in group size of Cantabrian chamois in relation to escape terrain and food
}

\author{
F. Javier PÉREZ-BARBERÍA and Carlos NORES
}

Pérez-Barbería F. J. and Nores C. 1994. Seasonal variation in group size of Cantabrian chamois in relation to escape terrain and food. Acta theriol. 39: 295-305.

The herd size of Cantabrian chamois Rupicapra pyrenaica parva (Cabrera, 1910) varied seasonally in relation to escape terrain and food availability in our study area (Asturias, north of Spain). The median group size of females without kids was 1 (mean $\pm \mathrm{SD}=1.62 \pm 1.00)$, females with kids was $4(5.59 \pm 5.42)$, males was $1(1.73 \pm 1.78)$, and mixed group size was $7(8.91 \pm 7.91)$. The female-kid group size depended more on escape terrain availability than on food quality. Throughout the early weeks of the life of kids, the mothers remained in difficult access areas (cliffs and steep slopes), and showed a weak tendency to aggregate. These areas provided a wide visual range and hiding places for offspring and their use may be an anti-predation strategy. When the kids were able to run quickly, the mothers used subalpine meadows. These areas were very open and exposed kids to predation and human disturbance, however the forage has high nutritive value, and may compensate for the cost of breeding and suckling by the mothers. Aggregation may be selected as an anti-predation strategy in subalpine meadows, allowing a reduction in time spent vigilant by each individual in the group, and increased time available for other activities. The largest male groups were located in pastures with abundant but poor quality forage. Our results suggest that group size in Cantabrian chamois is very flexible, changing seasonally and in response to resource availability.

Key words: Rupicapra pyrenaica parva, group size, escape terrain, food

Facultad de Biología, Departamento de Biología de Organismos y Sistemas, Universidad de Oviedo, 33071-Oviedo, Spain

\section{Introduction}

Variations in spatial-temporal food distribution can cause aggregation or dispersal of the individuals in a population. When food is scarce, animals can migrate or remain in the same area and disperse to avoid competition for food. Aggregation of prey species as an anti-predation strategy is useful when vigilance is the main defense mechanism (Cushing and Harden 1968, Pulliam and Mills 1977, Caraco et al. 1980). Increased group size reduces vigilance time for each individual, optimizing time for other activities (Caraco 1979a, b, Pulliam and Caraco 1984, Quenette 1990). Demands of each sex may be different, due to sexual dimorphism (Staines et al. 1982) or the biological cycle of each sex, and so food availability and the risk of predation influences group size of both sexes differently. 
To predict optimal group size, it is necessary to consider costs and benefits that aggregatio provides to every individual at that moment (Caraco 1981). Consequently, stable group size occurs rarely (Pulliam and Caraco 1984). An increase in group size may imply a reduction of the risk of predation, but it also increases competition for food within the group (Caraco 1979a, b, 1981).

The aim of this study was to describe the annual variation in group size of the Cantabrian chamois Rupicapra pyrenaica parva (Cabrera, 1910) in North of Spain, in relation to the influence of escape terrain and food quality.

\section{Study area}

The study area was located in a $12.2 \mathrm{~km}^{2}$ valley in the Game Reserve of Reres, Cantabrian Mountains, north of Spain. Altitude ranged from 900 to $1,709 \mathrm{~m}$ a.s.l. A large portion (39\%) of the study area is composed of siliceous soils which are vegetated with heathers (Erica australis, E. arborea and Calluna vulgaris). Scrub Genista hispanicallegionensis (14\%) and subalpine meadows (9\%) dominate calcareous soils. The dominant tree species are Fagus sylvatica $(28 \%)$ and Betula pubescens $(2 \%)$. Hunting activity was low, with a harvesting rate of less than $6 \%$ per year. The natural predators of kid chamois are fox Vulpes vulpes and golden eagle Aquila chrysaetos, with wolf Canis lupus being the sole predator of adult chamois. Human presence was occasional throughout the year. Livestock (cattle, horses and goats) were only present between June and September. From November 1991 to November 1992 the chamois population in the area was estimated at $170 \pm 10$ individuals.

\section{Methods}

Foot surveys were carried out between November 1991 and November 1992 with a periodicity of two to six per month. Some surveys were interrupted by unfavourable weather conditions. During each survey group size, age and sex of each individual was recorded, and the groups' location was marked on an aerial photograph $(1: 4,500)$. The age classes considered were: kids (animals $<1$ year old), yearlings ( $\geq 1$ and $<2$ years), and adults ( $\geq 2$ years), using the Berducou and Bousses (1985) classification. A group was considered as the aggregation of chamois where no individual was more than $50 \mathrm{~m}$ from any other animal in the same group (Clutton-Brock et al. 1982). Solitary chamois were considered as a group of size 1 . Records obtained inside the forest $(n=16)$ were excluded, due to the low detectability of chamois in these areas which did not allow correct surveys, thus group size was underestimated (Hirth 1977). A total of 970 sightings of chamois groups were recorded, 135 sightings were excluded from the calculations because our presence changed their size, or the sex or the age of individuals could not be determined.

The group classes considered were: adult females without kids or yearling (female-no-kid), adult females with kids or yearlings (female-kid), males, and mixed groups having at least one adult male and one adult female.

The study area was categorized as follows:

1. Escape terrain. A herd was considered to be in a escape terrain when located on cliffs or slopes of more than $45^{\circ}$. These areas protect chamois from natural predators and human disturbance (Cederna and Lovari 1985, Patterson 1988). Vegetation types of this area were: scrub and heath.

2. Food quality. Four different habitats were selected: subalpine meadow, scrub, heath and rocky ground. Vegetation samples were collected between June and August, with the exception of rocky ground because its vegetation type was the same as of heath habitat. Nutrient content and percentage cover of different habitats are shown in Table 1. The different habitats are described as follows: 
Table 1. Nutrient content and percentage cover in four habitat types of the study area. These habitat were significantly different in protein (ANOVA, $\left.F_{2,8}=10.984, p=0.005\right)$ and $\operatorname{IVD}\left(F_{2,8}=5.099\right.$, $p=0.037$ ). Protein - percentage of crude protein in the dried matter (Kjeldahl nitrogen $\times 6.25$ ), NDF - percentage of neutral detergent fibre, IVD - percentage of in vitro digestibility matter, it was estimated in relation to digestibility with cellulase from Trichoderma viridae. ${ }^{1}$ Percentage cover was estimated using line-intercept method (Mueller-Dombois and Ellenberg 1974), ${ }^{2}$ cover measurements were not taken; approximately $100 \%$ grass cover (visual estimation), ${ }^{3}$ nutrient content as heath, ${ }^{4}$ number of points sample to cover estimation, ${ }^{5}$ number of samples to nutrient content analysis.

\begin{tabular}{|c|c|c|c|c|c|c|c|c|c|c|c|}
\hline \multirow{2}{*}{ Habitat } & \multicolumn{4}{|c|}{ Percentage cover ${ }^{1}$} & \multicolumn{2}{|c|}{ Protein } & \multicolumn{2}{|c|}{ NDF } & \multicolumn{2}{|c|}{ IVD } & \multirow[b]{2}{*}{$n^{5}$} \\
\hline & Grass & Rock & Scrub & $n^{4}$ & Mean & SD & Mean & SD & Mean & SD & \\
\hline Subalpine Meadow ${ }^{2}$ & - & - & - & - & 18.10 & 2.45 & 56.40 & 3.15 & 66.35 & 1.98 & 5 \\
\hline Scrub of Genista & 15.07 & 39.71 & 45.22 & 272 & 13.16 & 5.07 & 50.64 & 9.31 & 63.97 & 6.28 & 3 \\
\hline Heath & 3.38 & 0.00 & 96.62 & 296 & 7.23 & 1.71 & 53.09 & 2.29 & 57.72 & 2.84 & 3 \\
\hline Rocky grounds $^{3}$ & 34.43 & 15.79 & 49.78 & 456 & - & - & - & - & - & - & - \\
\hline
\end{tabular}

Subalpine meadow: herbaceous communities with the most nutritive pastures. Scrub: the predominant species were Genista hispanica, G. legionensis, Erica vagans, Littodora diffusa, Festuca burgundiara and Brachipodium pinnatum. In these areas the chamois feed mainly on buds and flowers of Genista hispanica/legionensis, Erica vagans and grasses (visual records), the quality of these pastures was less than that of the subalpine meadow (see Table 1). Heath: areas having low quality food in relation to the other vegetation types, predominant species being Calluna vulgaris, Erica australis, E. arborea, E. cinerea, E. tetralix and Genistella tridentatum. Here chamois consumed mainly $C$. vulgaris and $E$. cinerea (visual records). Rocky ground: heath affected by fire, and vegetation scarce. Temporary communities of grasses (Deschampsia flexuosa) grew in these places, together with scattered plants of $E$. australis, $C$. vulgaris and $E$. cinerea. The quality of these pastures was assumed to be similar to heath, but the quantity of food stuff was very low in comparison with heath areas (Rocky grounds cover versus heath cover: $\chi^{2}=181.64, \mathrm{df}=1, p \ll 0.0001$. Vegetation height of rcky ground versus heath: Mann-Whitney $U$-test, $\mathrm{Z}=-11.71, p<<0.0001$ ).

The median has been chosen to characterize group size, since in most classes frequency distributions were very asymmetrical and could not be normalized. In these cases the median described the central tenlency better than the mean (Sokal and Rohlf 1981, Zar 1984). Other studies concerning group size have also used the median (Clutton-Brock et al. 1982, Lovari and Cosentino 1986, Jeppesen 1987). However, in order to compare our data with other studies which utilize mean group size, we have incluced means and standard deviations. All statistical tests were made using the median. Median tess for more than two samples were used to establish differences among group size (with the statistis $\chi^{2}$ when the number of degrees of freedom was more than 2 and the number of cases greater than 30 , and the Fisher exact test when the number of cases was less than 30 with one degree of freedom; Norusis 1986). The Tukey's test of multiple comparisons was used for the median ( $\alpha=$ 0.05 ) accoring to Levy (in Zar 1984). The use of $\chi^{2}$ statistics is probably not suite proper because our data are partly dependent, but as for as we know, no better statistical analysis exist for our case.

\section{Results}

\section{Dynamics of group size}

Median group size among classes differed throughout the year (Table 2) and all pairs of classes were different, with the following exceptions: female-no-kid 
versus male groups in autumns 1991 and 1992, spring 1992, and summer 1992, female-kid versus mixed groups in autumn 1991 and spring 1992 (Table 2). Throughout the year mixed groups generally exhibited the largest size, followed by female-kid groups, male groups and female-no-kid groups. There were also significant differences among classes within seasons. No class showed a significant change in the median between seasons (median test, $p>0.1$ in all cases).

Table 2. Comparisons of chamois group sizes and differences between classes within seasons (median test). The pairs of groups with no significant differences are shown (multiple comparisons among medians, Tukey test, $\alpha=0.05$ ). ${ }^{* * *}-p<0.001$.

\begin{tabular}{|c|c|c|c|c|c|c|c|}
\hline \multirow{2}{*}{ Season } & \multicolumn{4}{|c|}{ Group classes } & \multirow{2}{*}{$\chi^{2}$} & \multirow{2}{*}{ df } & \multirow{2}{*}{$\begin{array}{l}\text { Group } \\
\text { pairs }\end{array}$} \\
\hline & Female-no-kid & Female-kid & Males & Mixed & & & \\
\hline
\end{tabular}

Autumn 1991

median

1

SD 1.50

\section{4}

4.93

3.93

$2-20$

31

14

$n$

Winter 1992

median

mean

SD

range

$n$

Spring 1992

median

mean

SD

range

$n$

Summer 1992

\section{median}

mean

SD

range

$n$

Autumn 1992

$\begin{array}{ll}\text { median } & 1 \\ \text { mean } & 1.31 \\ \mathrm{SD} & 0.54 \\ \text { range } & 1-3 \\ n & 29\end{array}$

31
6

8.11

5.84

2-27

63

$\begin{array}{lll}4 & 1 & 7.5 \\ 4.39 & 1.96 & 9.05 \\ 2.27 & 2.31 & 8.76 \\ 2-12 & 1-16 & 2-55 \\ 28 & 80 & 40\end{array}$

$\begin{array}{llll}4 & 1 & 4\end{array}$

$\begin{array}{lll}6.56 & 1.57 & 5.22\end{array}$

$\begin{array}{lll}6.34 & 1.68 & 3.80\end{array}$

2-26 1-8 2-14

37

9

$\begin{array}{lll}3 & 1 & 8 \\ 6.47 & 1.78 & 13.52 \\ 7.02 & 1.94 & 12.52 \\ 2-33 & 1-11 & 3-43 \\ 62 & 64 & 21\end{array}$

$\begin{array}{llll}4 & 1 & 7\end{array}$

87.37

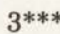

1-3 


\section{Group size and escape terrain availability}

Female-kid groups were smaller in areas of escape terrain than elsewhere throughout all seasons, with the exception of the autumn 1991 and spring 1992 (Table 3). Only male groups were larger in the non-escape terrain areas in summer. Female-no-kid and mixed groups did not show differences in group size between escape terrain and non-escape terrain areas.

\section{Group size and food}

Female-no-kid group size did not show differences between areas in any season (Table 4). The same occurred in female-kid groups. Male group size differed between habitats in winter and summer. In winter the largest groups were located

Table 3. Comparison of chamois group sizes in escape terrain and elsewhere areas. Median test, ${ }^{*}-p<0.05,{ }^{* *}-p<0.01,{ }^{* * *}-p<0.001$.

\begin{tabular}{|c|c|c|c|c|c|c|c|c|}
\hline & \multicolumn{8}{|c|}{ Group classes } \\
\hline & \multicolumn{2}{|c|}{ Female-no-kid } & \multicolumn{2}{|c|}{ Female-kid } & \multicolumn{2}{|c|}{ Males } & \multicolumn{2}{|c|}{ Mixed } \\
\hline & $\begin{array}{l}\text { escape } \\
\text { terrain }\end{array}$ & $\begin{array}{c}\text { non-escape } \\
\text { terrain }\end{array}$ & $\begin{array}{l}\text { escape } \\
\text { terrain }\end{array}$ & $\begin{array}{c}\text { non-escape } \\
\text { terrain }\end{array}$ & $\begin{array}{l}\text { escape } \\
\text { terrain }\end{array}$ & $\begin{array}{c}\text { non-escape } \\
\text { terrain }\end{array}$ & $\begin{array}{l}\text { escape } \\
\text { terrain }\end{array}$ & $\begin{array}{c}\text { non-escape } \\
\text { terrain }\end{array}$ \\
\hline \multicolumn{9}{|c|}{ Autumn 1991} \\
\hline median & 1 & 1 & 3 & 5.5 & 1 & 1 & 4 & 7.5 \\
\hline mean & 1.40 & 1.71 & 3.43 & 6.44 & 1.50 & 1.74 & 5.44 & 9.61 \\
\hline $\mathrm{SD}$ & 0.55 & 1.25 & 1.81 & 4.90 & 1.17 & 1.36 & 3.32 & 6.53 \\
\hline$n$ & 5 & 7 & 7 & 16 & 28 & 57 & 9 & 38 \\
\hline \multicolumn{9}{|c|}{ Winter 1992} \\
\hline median & 1 & 1 & 3.5 & $5^{*}$ & 1 & 1 & 7 & 8 \\
\hline mean & 2.00 & 1.89 & 4.17 & 5.76 & 1.72 & 2.37 & 6.40 & 10.90 \\
\hline SD & 1.22 & 1.24 & 2.98 & 2.61 & 1.72 & 2.99 & 4.28 & 11.18 \\
\hline$n$ & 9 & 19 & 12 & 17 & 39 & 51 & 5 & 29 \\
\hline \multicolumn{9}{|c|}{ Spring 1992} \\
\hline median & 1 & 4 & 4 & 6 & 1 & 1 & 5 & 3 \\
\hline mean & 1.20 & 3.14 & 6.40 & 8.00 & 1.14 & 2.14 & 7.00 & 3.00 \\
\hline SD & 0.56 & 1.57 & 5.15 & 5.23 & 0.45 & 3.04 & 5.66 & 1.00 \\
\hline$n$ & 15 & 7 & 25 & 7 & 28 & 22 & 4 & 3 \\
\hline \multicolumn{9}{|c|}{ Summer 1992} \\
\hline median & 1 & 1 & 2 & $12^{* * *}$ & 1 & $1^{* *}$ & 7 & 7 \\
\hline mean & 1.31 & 1.47 & 4.06 & 13.95 & 1.21 & 2.47 & 6.86 & 16.77 \\
\hline SD & 0.74 & 0.74 & 3.33 & 9.49 & 0.73 & 2.66 & 4.02 & 16.36 \\
\hline$n$ & 26 & 15 & 34 & 20 & 34 & 43 & 7 & 13 \\
\hline \multicolumn{9}{|c|}{ Autumn 1992} \\
\hline median & 1 & 1 & 2 & $5^{* * *}$ & 1 & 1 & 5.5 & 8 \\
\hline mean & 1.25 & 1.67 & 2.87 & 6.68 & 1.50 & 2.00 & 5.83 & 10.40 \\
\hline $\mathrm{SD}$ & 0.45 & 1.24 & 1.12 & 4.59 & 1.33 & 2.47 & 2.48 & 7.84 \\
\hline$n$ & 12 & 18 & 15 & 19 & 34 & 50 & 6 & 25 \\
\hline
\end{tabular}




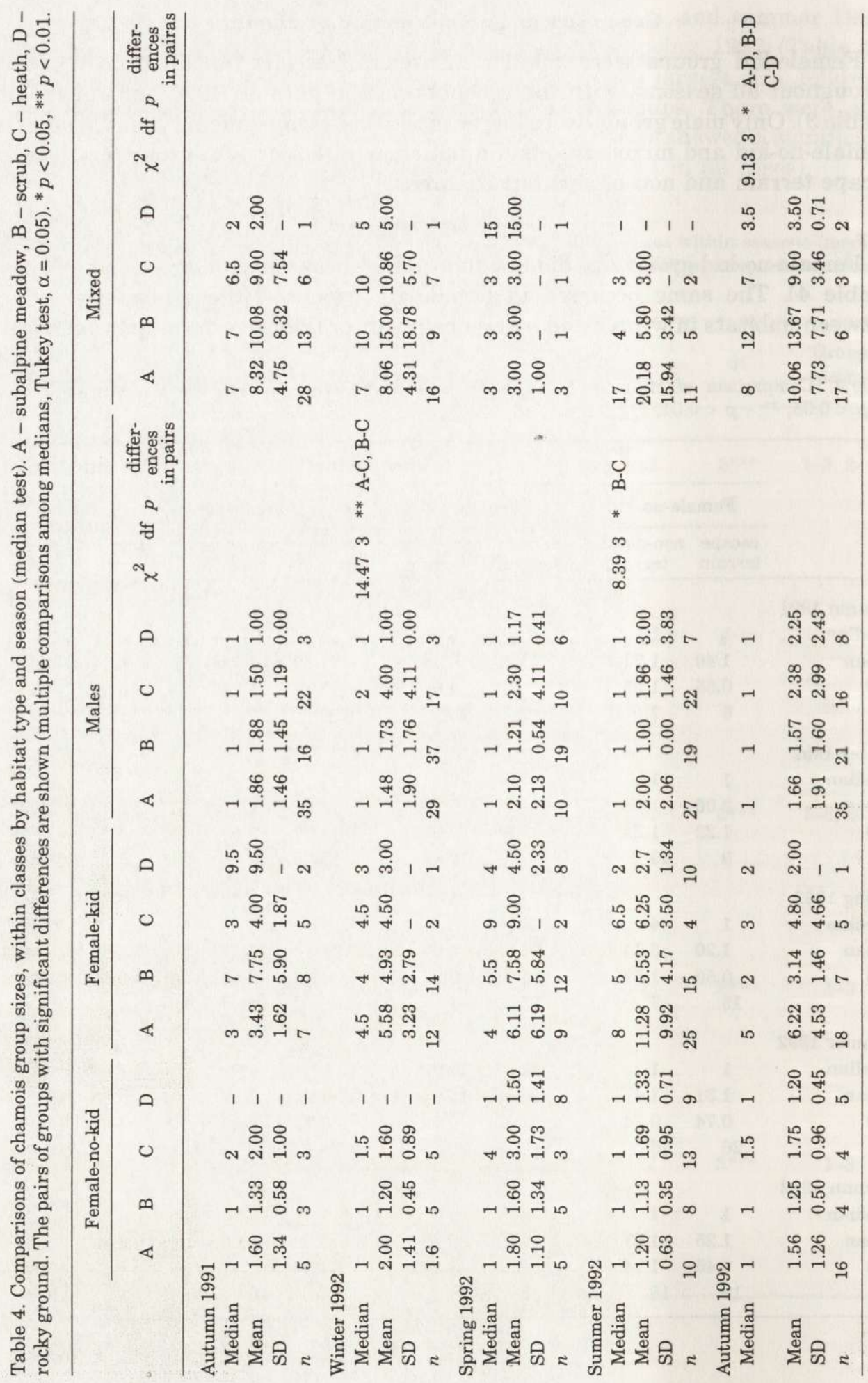


on heath, and not in habitats with more nutritious forage (subalpine meadow and scrub). In summer, male group size was greater in heath than in scrub. Mixed group sizes were different only between habitats in autumn 1992. During this season, the largest groups were located on subalpine meadow, scrub and heath as opposed to rocky ground.

\section{Discussion}

\section{Dynamics of group size}

Chamois group sizes vary greatly among geographical areas, with no consistent arguments to explain the variation between study areas (Krämer 1969, Berducou and Bousses 1985, Elsner-Schack 1985, Lovari and Cosentino 1986, Richard and Pépin 1990, Clarke and Frampton 1991). Berducou and Bousses (1985) suggested that larger aggregations of chamois in their study area could be due to high population density, although this has been doubted by Lovari and Cosentino (1986). Using surveys from 24 different areas in the Cantabrian Mountains we found that chamois group size could be density-dependent (median $=0.193 \times$ density $+2.013, r^{2}=0.453, F_{1,22}=18.235, p=0.0003 ;$ F. J. Pérez-Barbería and C. Nores, unpubl.). However this could be because in areas of high density different groups come together in the same foraging places and several groups can be falsely considered as one group. Also group size may depend on correlated factors, which are highly variable between study areas, including predation, availability and spatial-temporal distribution of foods, population structure and density.

The differences between group size of the classes throughout the year suggests that the cost/ benefit ratio for aggregating was different for each class. Presence of offspring appeared to be an important factor in determining a tendency to aggregate. Group size was similar throughout the year in the classes without kids (female-no-kid and male groups). This occurred in classes with kids (female-kid and mixed groups), in autumn and spring. The main difference between female-no-kid and male groups was that female-no-kid groups never exceeded 5 individuals, vhile male groups formed larger aggregations (up to 16 individuals) and were more stable with time. It is necessary to denote that some comparisons among group sizes are biased due to class group definitions. By definition, some groups (male and female-no-kid) can be formed by one individual, but female-kid and mixed groups always comprise at least two individuals.

\section{Group size and escape terrain}

Vigilance time spent by each individual can be reduced by an increase in group size. This allows each individual to spend more time in other activities (Pulliam and Mills 1977), but larger groups increase the number of aggressive interactions 
between individuals (Caraco 1979b, Clutton-Brock et al. 1982). Aggregation isonly useful when the cost/benefit balance increases the Darwinian fitness of the individual (Focardi and Paveri-Fontana 1992). Our results showed that femalt-kid group size was larger in non-escape terrain areas than in escape terrain areas, and the only seasons where differences were not significant were autumn 1991 and spring 1992. Escape terrain areas had steep slopes and cliffs where chanois found protection (Cederna and Lovari 1985). On these sites, chamois were able to run quickly, detected the proximity of predators, and were seldom disturbet by tourists or shepherds. Some authors have suggested that aggregation in open areas is favoured for increasing visual contact between members of the group (Firth 1977, Jodra 1981, Elsner-Schack 1985, Lagory 1986, Lovari and Cosentino 1986, Richard-Hansen et al. 1992). However, in our study, some escape terrain areas (steep slopes) have good visibility, similar to non-escape terrain areas. Thereore, the increase in group size could be seen as an anti-predation strategy. Lagory (1986) found the largest groups of white-tailed deer in open areas. He found that the time spent vigilant by each individual did not decrease in groups fourd in open areas, and, therefore, aggregation was not an anti-predation strategy in tiose situations. However, although vigilance time was similar between the areas studied by Lagory, large groups in open areas involve more eyes and this may entail a higher probability of detecting predators. Aggregation strategy was only useful to chamois when their anti-predator strategy entails running avay. Pregnant females, however, sought rugged and difficult access areas (Bousses and Cornaire 1982, and pers. obs.) where they remained until the kids were abe to run. In these circumstances, aggregation was not useful as an anti-precator strategy because increased group size would make detection of kids easier. Our results were consistent with this hypothesis. Female-kid groups in non-es:ape terrain areas were not significantly larger than in escape terrain areas in spring (the median of female-kid groups is 3 at early calving time, late April, and 55 in June) and in summer, the female-kid groups were again significantly larger in non-escape terrain areas (median $=12$ ) than in escape terrain areas (medien = 8). By summer, kids could run quickly and the mothers then moved to subabine meadows, where they found nutritious pastures, but were more exposed to predation and disturbance by humans. Under these conditions, the aggregation strategy might be useful. In cervids, it is also common for pregnant females to be isolated and seek habitat types that offer protection for their offspring (Cervus elaphus - Clutton-Brock et al. 1982, Dama dama - San Jose and Braza 1 1992), even though these areas may have forage with low nutrional value (Cervus elafhus - Jeppesen 1987). Other studies have also reported larger group sizes in son-escape terrain areas in several species (Odocoileus virginianus - Hirth 1977, Capra pyrenaica - Alados 1985, Ovis canadensis mexicana - Krausman el al. 1989). Male groups showed significant differences in group size between escape terrain and non-escape terrain areas only in summer, which could be due to difference food availability. 


\section{Group size and food}

Female-no-kid group size did not change among habitat types. It is difficult to know whether these groups were dependent on any particular factor, or whether the aggregations were only casual, due to the low aggregational tendency of this class (Lovari and Cosentino 1986, Richard-Hansen et al. 1992). The use of areas with highly nutritious forage by female-kid groups may compensate the energy cost to the mothers for breeding and suckling (Clutton-Brock et al. 1982), but escape terrain availability seemed to be more important during calving time, since female-kid groups located on rich nutritional areas were not greater than those on other areas.

The largest mixed groups were located on areas with high quality forage, the smallest on rocky ground. The food on rocky ground is very scarce and scattered, and therefore prevents aggregation. It would be expected that group size of this class would be similar to the female-kid group, because mixed groups are formed by females and males, and often kids. However, with respect to escape terrain and foods, the pattern of mixed group size was very different from the pattern of female-kid group size. Perhaps the presence of males in the mixed groups may explain this difference. We do not know if the males of these groups were leaders which could influence group location or whether mixed groups were casual aggregations, with the exception of mixed groups formed during the rut.

Male groups did not form during the rut (November). Males interrupt feeding activity almost totally and spend their time trying to dominate a small harem. Males consume a high percentage of their fat reserves during the rut (as in Cervus elaphus - Mitchell et al. 1976, Rangifer tarandus - Reimers and Ringberg 1983). Therefore, it would be expected that before and after the rut, the largest male groups would be found in habitats with highly nutritious forage. However, in summer and winter, the largest male groups were located in the heath areas. We propose two explanations: (1) Male chamois are using high quality patches which are scattered in heather habitat. These patches would have enough area and quality to favour aggregation (Pulliam and Caraco 1984, Krebs and Davies 1987, McNaughton 1988, Fryxell 1991), (2) Male energy requirements can be supplied by poor quality but abundant food, as it has been shown for red deer populations (Clutton-Brock et al. 1982, Staines et al. 1982). Males are able to ingest greater quantities of food by weight than females (Staines et al. 1982).

The differences in group size within classes or with respect to escape terrain availability or food quality in autumn was different between years (1991-1992). This may be due to the influence of weather conditions on plant biomass and production (Albon and Clutton-Brock 1988). Our study suggest that group size is very flexible, changing in response to variations in resource availability and the annual reproductive cycle of individuals.

Acknowledgements: We thank R. Rodríguez for putting his hut at our disposal during the study. We are indebted to G. Mutuberría, J. Ruiz, A. Nuño, P. García, J. Luengo, G. Rodríguez, P. Velasco, J. Oliveiros, C. Menéndez, M. Herrero, P. Herrero, L. M. Alonso and A. Luaña for their help in the field 
work, and also to game keepers J. Coya, C. Calvo and F. Simón. O. Hernández assisted in several aspects of this study. A. Argamentería made the pasture analysis. The authors acknowledge the instructive advice of F. Braña, Professor at the Departamento de Biología de Organismos y Sistemas, Universidad de Oviedo, to two anonymous reviewers and to C. Waterfield for her revision of our English. The research was supported by CICYT (Project $n^{\circ}$ 91-0911-FOR-217) and Consejería de Medio Ambiente y Urbanismo del Principado de Asturias (Grant 04-060-91). During the realization of this study, the senior author held a grant from FICYT.

\section{References}

Albon S. D. and Clutton-Brock T. H. 1988. Climate and the population dynamics of red deer in Scotland. [In: Ecological Changes in the Uplands. M. B. Usher and D. B. A. Thompson, eds]. Blackwell Scientific Publication, Oxford

Alados C. 1985. Group size and composition of the Spanish ibex (Capra pyrenaica Schinz) in the Sierras of Cazorla and Segura. [In: The biology and management of mountain ungulates. S. Lovari, ed]. Croom-Helm, London: 134-147.

Berducou C. and Bousses P. 1985. Social grouping patterns of a dense population of chamois in the Western Pyrenees National Park, France. [In: The biology and management of mountain ungulates. S. Lovari, ed]. Croom-Helm, London: 166-175.

Bousses P. and Cornaire S. 1982. L'ontogenese du comportement de jeune isard. Doc. Sci. Parc National des Pyrénées 10: 1-125.

Caraco T. 1979a. Time budgeting and group size: a theory. Ecology 60: 611-627.

Caraco T. 1979b. Time budgeting and group size: a test of theory. Ecology 60: 618-627.

Caraco T. 1980. Stochastic dynamics of avian foraging flock. Am. Nat. 115: 262-275.

Caraco T. 1981. Risk-sensitivity and foraging groups. Ecology 62: 527-531.

Caraco T., Martindale S. and Pulliam H. R. 1980. Avian flocking in the presence of a predator. Nature 285: 400-401.

Cederna A. and Lovari S. 1985. The impact of tourism on chamois feeding activities in an area of the Abruzzo National Park, Italy. [In: The biology and management of mountain ungulates. S. Lovari, ed]. Croom-Helm, London: 216-225.

Clarke C. M. H. and Frampton C. M. 1991. Structural changes in an apparently stable chamois population in Basin Creek, Canterbury, New Zealand. N. Zeal. J. Zool. 18: 233-241.

Clutton-Brock T. H., Guinness F. E. and Albon S. D. 1982. Red deer. Behaviour and ecology of two sexes. University of Chicago Press, Chicago: 1-378.

Cushing D. H. and Harden F. R. 1968. Why do fish school? Nature 218: 918-920.

Elsner-Schack I. von. 1985. Seasonal changes in the size of chamois groups in the Ammergauer Mountains, Bavaria. [In: The biology and management of mountain ungulates. S. Lovari, ed]. Croom-Helm, London: 148-153.

Focardi S. and Paveri-Fontana S. L. 1992. A theoretical study of the socioecology of ungulates. Theor. Popul. Biol. 41: 121-134.

Fryxell J. M. 1991. Forage quality and aggregation by large herbivores. Am. Nat. 138: 478-498.

Hirth D. H. 1977. Social behavior of white-tailed deer in relation to habitat. Wildl. Monogr. 53: 1-55.

Jeppesen J. L. 1987. Seasonal variation in group size, and sex and age composition in a Danish Red deer (Cervus elaphus) population under heavy hunting pressure. Dan. Rev. Game Biol. 13: 4-18.

Jodra P. J. 1981. Parámetros de gregarismo del Gamo (Dama dama) en el coto de Doñana. Doñana Acta Vertebrata 8: 237-289.

Krämer A. 1969. Soziale Organisation und Sozialverhalten einer Gemspopulation (Rupicapra rupicapra L.) den Alpen. Z. Tierpsych. 26: 889-964.

Krausman P. R., Leopold B. D., Seegmiller R. F. and Torres S. G. 1989. Relationships between desert bighorn sheep and habitat in western Arizona. Wildl. Monogr. 102: 1-66. 
Krebs J. R. and Davies N. B. 1987. An introduction to behavioural ecology (2nd edn). Blackwell Scientific Publications, Oxford: 1-389.

Lagory K. E. 1986. Habitat, group size, and the behaviour of white-tailed deer. Behaviour 98: 168-179.

Lovari S. and Cosentino R. 1986. Seasonal habitat selection and group size of the Abruzzo chamois (Rupicapra pyrenaica ornata). Boll. Zool. 53: 73-78.

McNaughton S. J. 1988. Mineral nutrition and spatial concentrations of African ungulates. Nature 334: 343-345.

Mitchell B., McCowan D. and Nicholson I. A. 1976. Annual cycles of body weight and condition in Scottish red deer (Cervus elaphus). J. Zool., Lond. 180: 107-127.

Mueller-Dombois D. and Ellenberg H. 1974. Aims and methods of vegetation ecology. John Wiley and Sons, New York: 1-547.

Norusis M. J. 1986. SPSS/PC+: SPSS for the IBM PC/XT/AT. Chicago.

Patterson I. J. 1988. Responses of Apennine chamois to human disturbance. Z. Säugetierk. 53: $245-252$.

Pulliam H. R. and Caraco T. 1984. Living in groups: is there an optimal group size?. [In: Behavioural ecology: an evolutionary approach. J. R. Krebs and N. B. Davies, eds]. Blackwell Scientific Publications, Oxford: 122-147.

Pulliam H. R. and Mills G. S. 1977. The use of space by wintering sparrows. Ecology 58: 1393-1399.

Quenette, P.-Y. 1990. Functions of vigilance behaviour in mammals: a review. Acta Oecologica 11: 801-818.

Reimers E. and Ringberg T. 1983. Seasonal changes in body weights of Svalbard reindeer from birth to maturity. Acta zool. fenn. 175: 69-72.

Richard C. and Pépin D. 1990. Seasonal variation in intragroup-spacing behavior of foraging isards (Rupicapra pyrenaica). J. Mammal. 71: 145-150.

Richard-Hansen C., Gonzalez G. and Gerard J.-F. 1992. Structure sociale de l'isard (Rupicapra pyrenaica) dans trois sites pyrénéens. Gibier Faune Sauvage 9: 137-149.

San José C. and Braza F. 1992. Antipredator aspects of fallow deer behaviour during calving season at Doñana National Park (Spain). Ethol. Ecol. Evol. 4: 139-149.

Sokal R. R. and Rohlf F. J. 1981. Biometry. The principles and practice of statistics in biological research. (2nd edn). W. H. Freeman and Company, New York: 1-859.

Staines B. W., Crisp J. M. and Parish T. 1982. Differences in the quality of food eaten by red deer (Cervus elaphus) stags and hinds in winter. J. Appl. Ecol. 19: 65-77.

Zar J. H. 1984. Biostatistical analysis (2nd edn). Prentice-Hall, New Jersey: 1-718.

Received 14 February 1994, accepted 16 May 1994. 